\title{
Epipubic bones of the Virginia Opossum (Didelphis virginiana) from México
}

\author{
Fernando A. Cervantes ${ }^{1 *}$, and Verónica Oviedo-Martínez ${ }^{1,2}$ \\ ${ }^{1}$ Colección Nacional de Mamíferos, Departamento de Zoología. Instituto de Biología, Universidad Nacional Autónoma de México. \\ Circuito Deportivo s/n, CP: 04510, Ciudad Universitaria. Ciudad de México, México. Email: fac@ib.unam.mx (FAC). \\ ${ }^{2}$ Departamento de Botánica y Zoología, Centro Universitario de Ciencias Biológicas y Agropecuarias. Universidad de Guadalajara. \\ Camino Ramón Padilla Sánchez 2100, Nextipac, 45200, Zapopan. Jalisco, México. Email: veroviedo@icloud.com (VO-M). \\ *Corresponding author
}

\begin{abstract}
The epipubic bones of the marsupials have been little studied and the meaning of their linear dimensions is poorly known. We therefore evaluated epipubic bone size of Virginia Opossum (Didelphis virginiana) from Mexico, and estimated their proportions relative to skull size of individuals. Results showed that males have larger skull and acetabulum size than females, epipubic bones of females are almost half the size of a female's skull while that of the male is a little less than a third of the male cranial size. Therefore, epipubic bones are an important landmark of sexual dimorphism in D. virginiana, and our data may be useful to learn more about epipubic bones of other marsupials.

Los huesos epipúbicos de los marsupiales han sido poco estudiados y se sabe poco del significado de sus dimensiones lineales. Por tanto, evaluamos el tamaño del hueso epipúbico en tlacuaches mexicanos (Didelphis virginiana) y calculamos su proporción en relación al tamaño craneal de los individuos. Confirmamos que los machos tienen mayor tamaño de cráneo que las hembras y encontramos lo mismo para el acetábulo, y que los huesos epipúbicos de las hembras son casi la mitad del tamaño del cráneo de una hembra, mientras que en machos son menos de un tercio del tamaño del cráneo. Por lo tanto, los huesos epipúbicos son un punto de referencia importante del dimorfismo sexual en $D$. virginiana, y nuestros datos pueden ser útiles para aprender más sobre los huesos epipúbicos de otros marsupiales.
\end{abstract}

Key words: Didelphidae; Didelphimorphia; marsupium; morphometrics; pelvic girdle.

๑ 2020 Asociación Mexicana de Mastozoología, www.mastozoologiamexicana.org

\section{Introduction}

Like platypus and echidnas (Subclass Prototheria) and some fossil placentals, marsupial mammals (Infraclass Marsupialia sensu Burgin et al. 2018) are characterized by the presence of epipubic bones (Reilly and White 2003), which are not found in current members of Infraclass Placentalia (sensu Burgin et al. 2018). These are paired bony structures that articulates with the pubis and extend forward into the ventral abdominal wall (Marshall 1979). In most species they are long bones, depressed and apically sharp, and have two faces, two edges and two ends (Ferrusquia-Villafranca 1964). Therefore, the pelvic girdle of the marsupials is composed of the bones ilium, ischium, pubis, and epipubics (Figura 1).

Function of epipubic bones of marsupials presumably reflects emphasis on different but non-mutually exclusive functions. It has been proposed, on one hand, that they serve as a support mechanism for the marsupium or pouch and the offspring that are found inside by helping the abdominal musculature in the support of the abdomen (Elftman 1929; White 1989). On the other, it has been stated that epipubic bones act as a lever to facilitate the rigidity of the body through the limbs during walking and jogging (Reilly and White 2003); both females and males have epipubic bones, but the latter lack a pouch in almost all species of marsupials. If these bony structures are linked to the presence of a marsupium to provide support, then males would be expected to show little developed epipu- bic bones. Accordingly, White (1989) reported that epipubic bones of species with marsupium, as Virginia Opossum (Didelphis virginiana) are longer, in general, in females than in males for a given mass (g); unfortunately, he did not report the dimensions of the epipubic bones he studied yet the size values of those bones he examined cannot be compared.

On the other hand, research data have shown that males adult Virginia Opossum are larger than females, condition that becomes apparent at the beginning of sexual maturity (Gardner 1982). Sexual dimorphism, therefore, may be a secondary consequence of reproductive activity; smaller size and lighter weight of females may be the result of spending more energy in rearing youngs (Gardner 1982; Taque 2003). Similarly, differences between sexes in cranial and mandibular dimensions were found in the Virginia Opossum from Georgia, USA (Patterson and Mead 2008). In addition, canine teeth of males, and pelvic and non-pelvic dimensions are larger as well (Tague 2003; Patterson and Mead 2009); unfortunately, none of these reports estimated epipubic bone size. In contrast, Ventura et al. (2002) informed that sexual dimorphism in size may not be a general pattern in Didelphis after examining South American opossums ( $D$. marsupialis, D. pernigra, and D. imperfecta). Therefore, the relationship between length of this pelvic girdle structure and length of an individual remains unexplored. 
Unfortunately, there are no data available on linear dimensions of both epipubic bones and specimens examined to evaluate these issues and to better understand the relationships between sexual dimorphism and epipubic bone size. However, Mexican species of opossum (Didelphidae) are a good data source to contribute further information about this topic, particularly $D$. virginiana. This is the most common opossum species in México, with a wide geographical distribution and with numerous specimens represented in biological collections (Gardner 1982; Astúa 2015).

The objective of this work is, then, to describe and measure the size of the epipubic bones for females and males of the Virginia Opossum from México and assess their size relative to a measurement of body length assessed as skull length. These results will also allow to estimate what percentage of the length of an individual, as revealed by skull length, represents the length of the epipubic bones and compare between sexes.

\section{Materials and Methods}

A total of 102 specimens of the Mexican Virginia Opossum (D. virginiana) deposited in the Mammal National Collection (CNMA) of Instituto de Biología, Universidad Nacional Autónoma de México (IBUNAM), were examined but a subsample of 45 ( 28 males and 17 females) adult specimens were included in the morphometric analysis due to their good preservation condition (Appendix 1). Adulthood was assessed according to the sequence of molar eruption and replacement of the last deciduous premolar (Gardner 1982), as well as fusion of the ilium, ischium, and pubis at the acetabulum (Tague 2003).

For each specimen, 16 pelvic and non-pelvic variables were taken with a digital vernier (Mitutoyo Co.) at a precision level of $0.01 \mathrm{~mm}$. Pelvic variables recorded were six measurements of the right epipubic bone (Figure 1a): Epipubic greatest length (EGL), Epipubic length from the base (ELB), Epipubic length from the process (ELP), Epipubic base width (EBW), Epipubic medium height (EMH), and Epipubic medium depth (EMD); six measurements of the pelvic girdle (Figure 1b, 1c): Pelvis width (PW), Ischium width (IW), Pubic symphysis length (PSL), Pubis to ischium distance (PID), Pubis to acetabulum greatest distance (PAGD), and length of the llium, from it joins the acetabulum to its anterior most end (LI); and two of the acetabulum (Figure 1c): Acetabular width (AW), Acetabular height (AH). Non-pelvic variables were two conventional cranial measurements: Skull greatest length (SGL), and Zygomatic width (ZW), recorded according to Ryan (2011). Statistical significance of Student's t-test was set at $P \leq 0.05$; when data were not normally distributed a non-parametric Wilcoxon test was utilized. In addition, we also examined specimens of other Mexican opossum species for comparative purposes.

To illustrate how the skull, epipubic bones, the rest of the pelvic girdle and the vertebrae of the sinsacral look like, we prepared digital files and uploaded them into the IREKANI collection of images of CNMA at IBUNAM available at http://unibio.unam.mx/irekani/.

\section{Results and Discussion}

Our results produced 16 digital files (numbers: 1260612621) containing photographs and curatorial data of juvenile, adult, female, and male specimens of the Mexican Virginia Opossum (D. virginiana), and the ring-tailed cat (Bassariscus astutus) just for visual comparative purposes with a placental mammal; for the first species resulted 14 files while just two for the latter species. One of the 14 files include the right epipubic bone of each species of Mexican opossums (Didelphidae). These are the first published data set that shows images of epipubic bones of Mexican species of opossums.

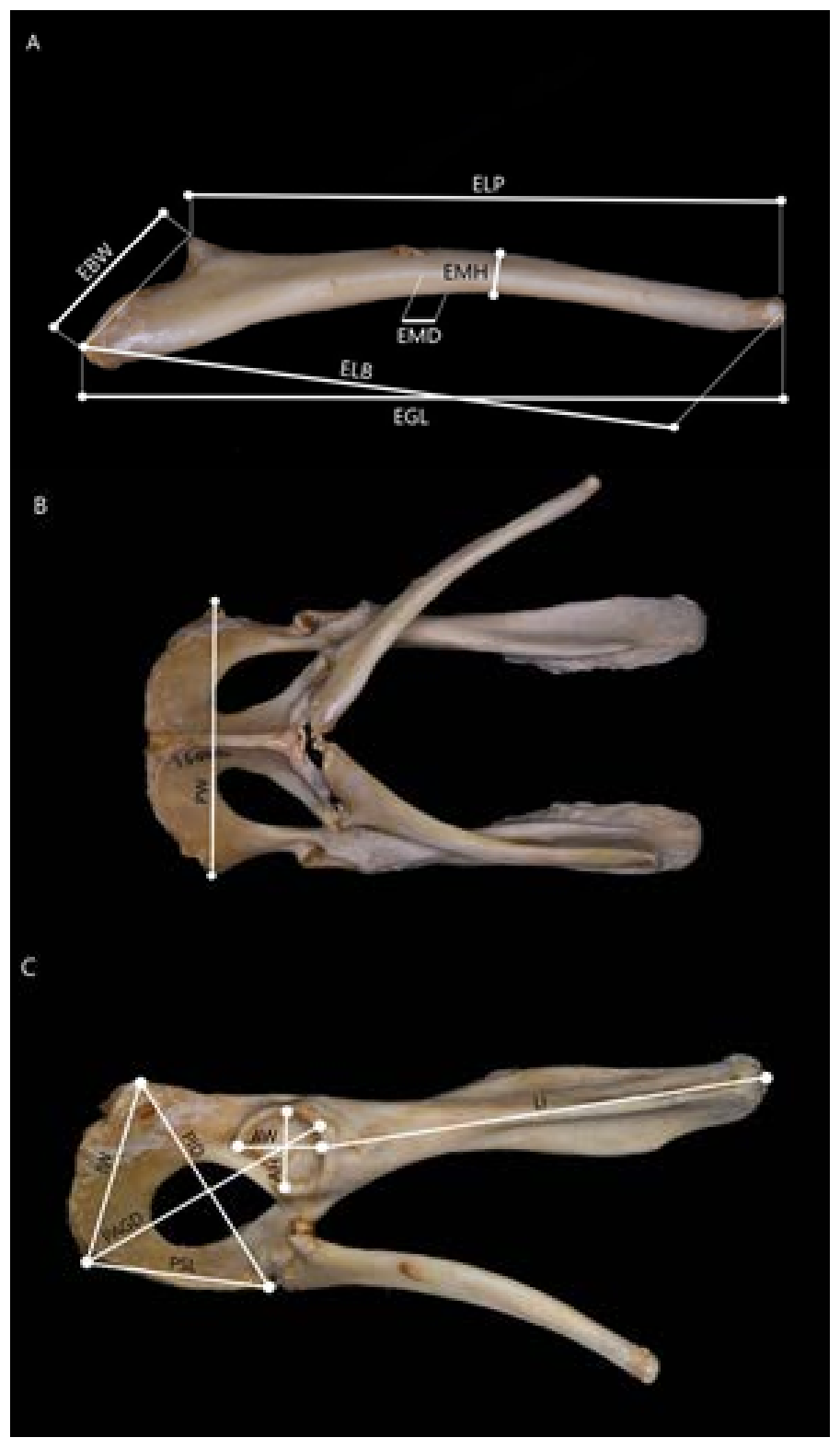

Figure 1. Pelvic measurements recorded in adult Mexican opossums (Didelphimorphia) from Mammal National Collection (CNMA) of Instituto de Biología, Universidad Nacional Autónoma de México (UNAM). A, lateral right view of the right epipubic bone. $B$, ventral view of the pelvic girdle. $C$, lateral right view of the pelvic girdle. Measurements names are indicated in text. 
The epipubic bone of the Mexican Virginia Opossum is a long, thin bone with a shape almost right to a slightly curved and a thickening with a notch at its base; the shape of this bone in young individuals is practically the same as in adults. It is located in the ventral part of the pelvic girdle, where it articulates with the right pelvic bone and extends towards the front and a little downwards almost parallel to the ilium bone of the pelvic girdle, coinciding with that reported by Tague (2003) who additionally points out that epipubics extend from the superior border of the pubis to approximately the plane of the sacroiliac joint. Similarly, we found that the epipubic bone of other Mexican opossum species of the genera Philander, Metachirus, Caluromys, Chironectes, Marmosa, and Tlacuatzin is also elongated, thin and little curved, what makes it similar in shape to that of Mexican Virginia Opossum specimens. In addition, Flores (2009) reported that the distal portion of the epipubic bones of Caluromys, Chironectes, and Marmosa is clearly curved. Ferrusquía-Villafranca (1964)4 also mentioned that Chironectes minimus has an epipubic with an almost straight internal edge and the outer tubercle of the proximal end not very prominent, like Caluromys derbianus.

The two measurements of acetabulum size and those of length and width of skull of Mexican D. virgininana showed that males are larger than females. That is, the average values of the Acetabular width (AW), Acetabular height (AH), Skull greatest length (SGL), and Zygomatic width (ZW) had a significantly higher mean value in males than in females (Table 1); larger acetabulum may articulate with a larger femur head of a larger femur. Other research on the pelvic sexual dimorphism in the Virginia Opossum (Tague 2003) revealed that in general males have pelvis larger than females, since 14 of 16 absolute dimensions of the pelvis were significantly higher in males. Unfortunately, no data on acetabulum dimensions were provided therein. Provided that these variables may be estimators of size, our data then agree with previous reports for North American populations of this species (Gardner 1982; White 1989), that adult males of the Virginia Opossum are larger than females.

However, we did not find significant differences between sexes regarding the other six measurements we recorded for other pubic bones. This is, lengths, widths and distances involving ilium, ischium, and pubis (PW, IW, PSL, PID, PAGD, and $\mathrm{Ll}$; Table 1). This result is similar to that reported by Elftman (1929) and Ferrusquía-Villafranca (1964)4 who mention that pelvis of females and males are not different from edach other in D. virginiana, P. opossum and C. minimus.

Interestingly, we also found that although males display longer acetabulum, females have longer epipubic bones (mean EGL $=4.4 \mathrm{~cm}$ ) than males (Table 1). This evidence of sexual dimporphism is supported by the variables Epipubic greatest length (EGL), Epipubic length from the base (ELB), and Epipubic length from the process (ELP) of females since are significantly larger than those that were recorded for males (Table 1). Our findings coincide with the results of
White (1989), who states that females generally have longer epipubic bones than males for a given mass (not length). Our data therefore using a linear variable, length $(\mathrm{mm})$, confirm what White (1989) reported using a variable of mass (g) regarding individual size between sexes. Ferrusquía-Villafranca (1964)4 also noted that females display relatively larger, more robust and curved epipubics than males.

In addition, our data showed then that the average greatest length of the epipubic bones (EGL) of adult males represents solely $29.13 \%$ of the size of the average total length of their skull (SGL), while in females this proportion reaches $47.78 \%$; the epipubic bone of females is also relatively larger than that for males. For instance, in our sample examined (Table 1) SGL and EGL of an adult male (CNMA 45122) are, respectively: 110.70 and $37.44 \mathrm{~mm}$, whereas for a female (CNMA 3523) these values are 97.36 and $47.22 \mathrm{~mm}$ (Figure 2). In contrast, the other three variables we recorded related with epipubic bones (Epipubic base width, EBW, Epipubic medium height, EMH, and Epipubic medium depth, EMD) did not show significant differences between sexes (Table 1).

Table 1. Descriptive statistics (mean, standard deviation, and range) and comparison of means of pelvic and non-pelvic variables $(\mathrm{mm})$ between sexes of adult Virginia Opossum (Didelphis virginiana). * = significant difference at 0.05 level.

\begin{tabular}{|c|c|c|c|c|}
\hline Variable & $\begin{array}{l}\text { Males } \\
(n=28)\end{array}$ & $\begin{array}{c}\text { Females } \\
(n=17)\end{array}$ & $\begin{array}{l}\text { Student's } \\
\text { t - test }\end{array}$ & $\begin{array}{l}\text { Wilcoxon } \\
\text { test }\end{array}$ \\
\hline $\begin{array}{l}\text { Epipubic greatest } \\
\text { length }\end{array}$ & $\begin{array}{r}38.45 \pm 4.43 \\
(31.00-44.27)\end{array}$ & $\begin{array}{r}43.97 \pm 7.48 \\
(27.78-54.33)\end{array}$ & $0.003^{*}$ & $0.001^{*}$ \\
\hline $\begin{array}{l}\text { Epipubic length } \\
\text { from the base }\end{array}$ & $\begin{array}{r}31.98 \pm 4.71 \\
(22.80-39.45)\end{array}$ & $\begin{array}{r}37.62 \pm 6.92 \\
(23.24-48.61)\end{array}$ & $0.009^{*}$ & $0.008^{*}$ \\
\hline $\begin{array}{l}\text { Epipubic length } \\
\text { from the process }\end{array}$ & $\begin{array}{r}33.42 \pm 4.09 \\
(26.40-40.09)\end{array}$ & $\begin{array}{r}39.51 \pm 6.87 \\
(24.78-50.07)\end{array}$ & $0.004^{*}$ & $0.002^{*}$ \\
\hline $\begin{array}{l}\text { Epipubic base } \\
\text { width }\end{array}$ & $\begin{array}{r}11.60 \pm 1.32 \\
(8.03-13.35)\end{array}$ & $\begin{array}{r}12.47 \pm 1.86 \\
(8.16-14.88)\end{array}$ & 0.117 & 0.105 \\
\hline $\begin{array}{l}\text { Epipubic medium } \\
\text { height }\end{array}$ & $\begin{array}{r}3.10 \pm 0.50 \\
(2.21-3.77)\end{array}$ & $\begin{array}{r}3.28 \pm 0.96 \\
(1.43-5.29)\end{array}$ & 0.497 & 0.421 \\
\hline $\begin{array}{l}\text { Epipubic medium } \\
\text { depth }\end{array}$ & $\begin{array}{r}1.79 \pm 0.36 \\
(1.13-2.44)\end{array}$ & $\begin{array}{r}1.98 \pm 0.64 \\
(0.56-2.82)\end{array}$ & 0.261 & 0.164 \\
\hline Pelvis width & $\begin{array}{r}40.94 \pm 5.28 \\
(34.25-48.12)\end{array}$ & $\begin{array}{r}37.20 \pm 6.35 \\
(24.27-43.8)\end{array}$ & 0.099 & 0.143 \\
\hline Ischium width & $\begin{array}{r}28.41 \pm 5.90 \\
(20.04-35.39)\end{array}$ & $\begin{array}{r}28.48 \pm 3.87 \\
(19.53-33.26)\end{array}$ & 0.555 & 0.69 \\
\hline $\begin{array}{l}\text { Pubic symphysis } \\
\text { length }\end{array}$ & $\begin{array}{r}21.11 \pm 3.16 \\
(12.74-25.06)\end{array}$ & $\begin{array}{r}20.42 \pm 3.5 \\
(12.57-24.63)\end{array}$ & 0.961 & 0.824 \\
\hline $\begin{array}{l}\text { Pubis to ischium } \\
\text { distance }\end{array}$ & $\begin{array}{r}32.04 \pm 3.74 \\
(23.92-37.84)\end{array}$ & $\begin{array}{r}30.16 \pm 3.65 \\
(21.37-34.9)\end{array}$ & 0.109 & 0.076 \\
\hline $\begin{array}{l}\text { Pubis to } \\
\text { acetabulum } \\
\text { greatest distance }\end{array}$ & $\begin{array}{r}35.76 \pm 3.79 \\
(27.12-42.56)\end{array}$ & $\begin{array}{r}34.49 \pm 3.95 \\
(24.88-38.79)\end{array}$ & 0.297 & 0.361 \\
\hline Length of the Ilium & $\begin{array}{r}48.50 \pm 4.09 \\
(37.21-55.79)\end{array}$ & $\begin{array}{r}48.42 \pm 6.86 \\
(32.96-56.45)\end{array}$ & 0.940 & 0.497 \\
\hline Acetabular width & $\begin{array}{r}9.87 \pm 1.18 \\
(7.37-12.39)\end{array}$ & $\begin{array}{r}8.77 \pm 1.09 \\
(6.70-11.05)\end{array}$ & $0.003^{*}$ & $0.004^{*}$ \\
\hline Acetabular height & $\begin{array}{r}9.49 \pm 1.12 \\
(7.57-11.45)\end{array}$ & $\begin{array}{r}8.18 \pm 1 \\
(6.17-10.07)\end{array}$ & $0.000^{*}$ & $0.001^{*}$ \\
\hline $\begin{array}{l}\text { Skull greatest } \\
\text { length }\end{array}$ & $\begin{array}{r}108.38 \pm 11.81 \\
(124.75-80.56)\end{array}$ & $\begin{array}{r}99.08 \pm 11.47 \\
(72.23-115.76)\end{array}$ & $0.014^{*}$ & $0.017^{*}$ \\
\hline Zygomatic width & $\begin{array}{r}56.56 \pm 7.16 \\
(40.18-70.68)\end{array}$ & $\begin{array}{r}50.35 \pm 6.31 \\
(36.44-58.98)\end{array}$ & $0.005^{*}$ & $0.007^{*}$ \\
\hline
\end{tabular}




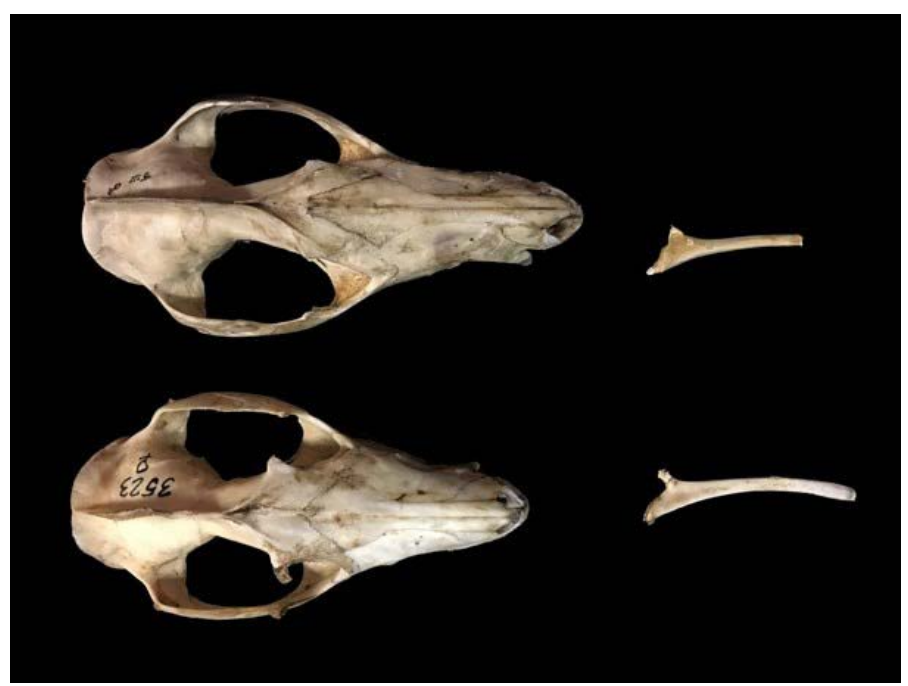

Figure 2. Skull length relative to epipubic bone length in adult Virginia Opossum (Didelphis virginiana) from México. Above: male (CNMA 45122); below: female (CNMA 3523). Body size of the first is larger but the latter has a larger epipubic bone.

Length of the epipubic bone for the two species of the genus Didelphis examined here, (D. virginiana and D. marsupialis) turned out to be the largest values in the sample for the opossum species of México. Accordingly, the smallest recorded epipubic bones corresponded to the smallest species of Mexican marsupials, the mouse opossums (Marmosa mexicana and Tlacuatzin canescens); females of these small marsupials do not have a marsupium; however, they display well developed epipubic bones. If proportionally small epipubic bones of mouse opossums is an evolutionary result of lack of marsupium remains to be tested. However, Flores (2009) reported larger development of epipubic bones in females of pouchless taxa.

Except $D$ virginiana, the small sample size available for other species of Mexican opossums prevents comparisons between species. However, a tendency can be noted where the length of the epipubic bones of $D$. virginiana, D. marsupialis, Philander opossum, Chironectes minimus and Metachirus nudicaudatus represent almost half the size of the skull. Similarly, Flores (2009) found that the proximal size of the epipubic bones is long in Didelphis, Caluromys, Philander and Marmosa (except M. rubra). In contrast, length of the epipubic bones of Caluromys derbianus, Marmosa mexicana, and T. canescens are around a third of skull length.

In summary, epipubic bones is an important distinctive characteristic of marsupials, it has been little studied and there are still few available data on its morphology. However, our study makes available by first time summarized data based on length and images on epipubic bones of Mexican species of opossums, particularly the Mexican Virginia Opossum.

Our data confirm that males of Mexican opossums Didelphis virginiana are larger than females, and that epipubic bones are significantly larger in the latter; epipubic bone length of a female is almost half size her skull length. Therefore, epipubic bones are an important landmark of sexual dimorphism in $D$. virginiana, and our data may be useful to learn more about epipubic bones of other marsupial mammals. Undoubtedly, further research is needed to better understand the role of epipubic bones in the structure and function of pelvic girdle of marsupials.

\section{Acknowledgements}

We are grateful to students and staff of Mammal National Collection (CNMA) that helped this project in the field, laboratory, and curatorial procedures, particularly to J. Vargas-Cuenca, and Y. Hortelano-Moncada. S. Guzmán kindly uploaded digital files to the CNMA image collection. The reviews of two anonymous reviewers and J. Servin helped improve this writing. We dedicate this contribution to faculty, staff, and students of Autonomous National University of México (UNAM) in charge of the natural protected area "Reserva Ecológica del Pedregal de San Ángel" (REPSA) in south México City for their selfless efforts for the biological conservation of $D$. virginiana and other local wildlife.

\section{Literature Cited}

AstúA, D. 2015. Family Didelphidae (Opossums). Pp. 70-186 in Handbook of the mammals of the world. Vol. 5. Monotremes and marsupials (Wilson, D. D., and R. A. Mittermeier, eds.). Lynx Edicions. Barcelona, España.

Burgin, C., J. Colella, P. Kahn, and N. Upham. 2018. How many species of mammals are there? Journal of Mammalogy 99:114.

Elftman, H. O. 1929. Functional adaptations of the pelvis in marsupials. Bulletin of the American Museum of Natural History 58:189-232.

Ferrusquia-Villafranca, I. 1964. Osteologia comparada de los marsupiales mexicanos Didelphis, Philander, Chironectes y Caluromys. Tesis de Licenciatura. Facultad de Ciencias, Universidad Nacional Autónoma de México. Distrito Federal, México.

FLoRes, D. A. 2009. Phylogenetic analyses of postcranial skeletal morphology in didelphid marsupials. Bulletin of the American Museum of Natural History 320:1-81.

GARDNER, A. L. 1982. Virginia Opossum. Didelphis virginiana. Pp. 3-36 in Wild mammals of North America (Chapman, J. A., and G. A., Feldhamer, eds.). Biology, management and economic. The Johns Hopkins University Press. Baltimore, U.S.A.

MARSHALL, L. G. 1979. Evolution of metatherian and eutherian (mammalian) characters: a review based on cladistic methodology. Zoological Journal of the Linnean Society 66:369-410.

Patterson, D., and A. J. Mead. 2008. Osteological variation within the Baldwin County, Georgia, population of Didelphis virginiana. The Southwestern Naturalist 7:125-134.

Patterson, D., And A. J. Mead. 2009. Sexual dimorphism within canine dimensions of Didelphis virginiana. Georgia Journal of Science 67:75-81.

RelLuY, S., AND T. White. 2003. Hypaxial motor patterns and the function of epipubic bones in primitive mammals. Science 299:400-402.

Ryan, J. M. 2011. Mammalogy techniques manual. 2nd edition. Raleigh. North Carolina, U.S.A. 
TAgue, R. G. 2003. Pelvic sexual dimorphism in a metatherian, Didelphis virginiana: implications for eutherians. Journal of Mammalogy 84:1464-1473.

Ventura, J., M. Salazar, R. Pérez-Hernández, and M. J. LópezFuster. 2002. Morphometrics of the genus Didelphis (Didelphimorphia: Didelphidae) in Venezuela. Journal of Mammalogy 83:1087-1096.

White, T. D. 1989. An analysis of epipubic bone function in mammals using scaling theory. Journal of Theoretical Biology 139:189-232.

Associated editor: Jorge Servín

Submitted: July 24, 2019; Reviewed: August 6, 2019;

Accepted: November 7, 2019; Published on line: November 26, 2019. 


\section{Appendix 1}

Museum specimens of adult opossums collected in México and examined to assess size variation of epipubic bones. All are deposited at Mammal National Collection (CNMA) of Instituto de Biología, Universidad Nacional Autónoma de México (UNAM). ${ }^{*}=$ day unknown; ${ }^{* *}=$ day and month unknown.

\begin{tabular}{|c|c|c|c|c|}
\hline $\begin{array}{l}\text { Catalog } \\
\text { number }\end{array}$ & Sex & Collection date & $\begin{array}{l}\text { Type of } \\
\text { preservation }\end{array}$ & Collecting locality \\
\hline \multicolumn{5}{|c|}{ Didelphis virginiana } \\
\hline 43395 & Male & 14 June 2006 & Skeleton only & Distrito Federal: Ciudad Universitaria, UNAM, Delegación Coyoacán, 2240 m. \\
\hline 43396 & Female & 11 April 2008 & Skin and skeleton & Distrito Federal: Ciudad Universitaria, UNAM, Delegación Coyoacán, 2240 m. \\
\hline 11305 & Female & 10 August 1968 & Skin and skeleton & Distrito Federal: Ciudad Universitaria, Delegación Coyoacán. \\
\hline 43393 & Female & 23 August 2007 & Skin and skeleton & $\begin{array}{l}\text { Distrito Federal: Jardín Botánico Exterior, Instituto de Biología, Ciudad Universitaria, UNAM. Delegación Coyoacán, } \\
2260 \mathrm{~m} \text {. }\end{array}$ \\
\hline 43392 & Female & 18 May 2004 & Skin and skeleton & $\begin{array}{l}\text { Distrito Federal: Jardín Botánico Exterior, Instituto de Biología, Ciudad Universitaria, UNAM. Delegación Coyoacán, } \\
2260 \mathrm{~m} \text {. }\end{array}$ \\
\hline 47207 & Male & 23 January 2011 & Skeleton only & Distrito Federal: Reserva Ecológica del Pedregal, Jardín Botánico, Delegación Coyoacán, 2326 m. \\
\hline 34644 & Male & December 1989* & Skin and skeleton & Distrito Federal: Reserva del Pedregal de San Ángel. UNAM. Coyoacán, 2250 m. \\
\hline 44100 & Female & 17 June 2011 & Skin and skeleton & $\begin{array}{l}\text { Distrito Federal: Jardín Botánico Exterior, Instituto de Biología, Ciudad Universitaria, UNAM. Delegación Coyoacán, } \\
2260 \mathrm{~m} \text {. }\end{array}$ \\
\hline 45114 & Male & 29 June 2008 & Skin and skeleton & Distrito Federal: Espacio Escultórico, Reserva del Pedregal de San Ángel, Ciudad Universitaria, Coyoacán, 2215 m. \\
\hline 34858 & Male & 9 January 1992 & Skin and skeleton & Distrito Federal: Cto. Exterior, Ciudad Universitaria, Delegación Coyoacán. \\
\hline 44101 & Male & 23 May 2011 & Skin and skeleton & Distrito Federal: Calle Corregidora 536, Col. Ampliación Miguel Hidalgo, Delegación Tlalpan. \\
\hline 44051 & Female & 1 March 2007 & Skin and skeleton & Distrito Federal: Reserva Ecológica del Pedregal de San Ángel de Ciudad Universitaria, Delegación Coyoacán, 2250 m. \\
\hline 44085 & Male & 30 March 2007 & Skeleton only & Distrito Federal: Reserva Ecológica del Pedregal de San Ángel de Ciudad Universitaria, Delegación Coyoacán, 2250 m. \\
\hline 43375 & Male & 1 May 2006 & Skeleton only & Distrito Federal: Reserva Ecológica del Pedregal de San Ángel de Ciudad Universitaria, Delegación Coyoacán, 2250 m. \\
\hline 43377 & Male & $2006^{* *}$ & Skin and skeleton & Distrito Federal: Reserva Ecológica del Pedregal de San Ángel de Ciudad Universitaria, Delegación Coyoacán, 2250 m. \\
\hline 43372 & Male & 31 August 2005 & Skin and skeleton & Distrito Federal: Reserva Ecológica del Pedregal de San Ángel de Ciudad Universitaria, Delegación Coyoacán, 2250 m. \\
\hline 43373 & Female & 9 September 2005 & Skin and skeleton & Distrito Federal: Reserva Ecológica del Pedregal de San Ángel de Ciudad Universitaria, Delegación Coyoacán, 2250 m. \\
\hline 3523 & Female & 11 September 1979 & Skin and skeleton & Guerrero: Viveros El Huayacán, La Poza, Municipio Acapulco. \\
\hline 652 & Male & 25 April 1978 & Skin and skeleton & Guerrero: Viveros El Huayacan, La Poza, Municipio Acapulco. \\
\hline 45117 & Male & 17 February 2009 & Skin and skeleton & Guerrero: Hotel y Villas “Las Flores”, 2.6 km SW Yetla, Municipio Coyuca de Benitez, 10 m. \\
\hline 45119 & Female & 3 February 2008 & Skin and skeleton & México: Campamento Ecoturístico “El Vivero”, 6.6 km SE Amecameca, Municipio Amecameca, 2849 m. \\
\hline 21866 & Male & 20 January 1985 & Skin and skeleton & Guanajuato: Sta. Catarina, Municipio Catarina, $1700 \mathrm{~m}$. \\
\hline 4158 & Female & 27 February 1980 & Skin and skeleton & Guanajuato: 18 km WSW Dolores Hidalgo, Municipio Dolores Hidalgo, 2275 m. \\
\hline 4159 & Female & 26 February 1986 & Skin and skeleton & Guanajuato: 8 km S San Miguel de Allende, Municipio San Miguel de Allende, 1920 m. \\
\hline 26464 & Male & 12 February 1983 & Skin and skeleton & Morelos: Campo cañero, Tlaltizapán. \\
\hline 26459 & Male & 9 February 1985 & Skin and skeleton & Morelos: 2 km SW Palpan, Municipio Miacatlan. \\
\hline 26461 & Male & 27 January 1985 & Skin and skeleton & Morelos: 3 km SW Palpan, Municipio Miacatlan. \\
\hline 18790 & Male & 25 February 1981 & Skin and skeleton & Guerrero: Puerto Marqués, Municipio Acapulco. \\
\hline 21989 & Female & 3 February 1985 & Skin and skeleton & San Luis Potosí: Racho Estribo, 10 km S Naranjo, Municipio Cuidad de Maíz. \\
\hline 3790 & Male & 23 February 1984 & Skin and skeleton & Puebla: Rancho La Carolina, Ayotoxco, Municipio Hueytamalco. \\
\hline 3792 & Female & 23 February 1984 & Skin and skeleton & Puebla: Rancho La Carolina, Ayotoxco, Municipio Hueytamalco. \\
\hline 38906 & Female & 22 March 1996 & Skin and skeleton & Oaxaca: 3 km W Sta. María del Mar, Municipio Juchitán. \\
\hline 44179 & Female & 23 November 2005 & Skeleton only & Oaxaca: San Pedro Mixtepec, 18 km N Puerto Escondido, Municipio San Pedro Mixtepec, 222 m. \\
\hline 47914 & Male & 28 December 2005 & Skin and skeleton & Oaxaca: Compañía Minera Cuzcatlán, 2.4 km SW San José del Progreso, Municipio San José del Progreso, 1590 m. \\
\hline 45141 & Male & 21 January 2007 & Skin and skeleton & Oaxaca: Barranca Amarilla, 1.05 km S, 3.75 km W Cosoltepec, Municipio Cosoltepec, 1650 m. \\
\hline 47899 & Male & 8 November 2011 & Skin and skeleton & Oaxaca: Compañía Minera Cuzcatlán, 2.13 km NW San José del Progreso, Municipio San José del Progreso, 1557 m. \\
\hline
\end{tabular}


Apendix 1 . Continuation

\begin{tabular}{|c|c|c|c|c|}
\hline 47900 & Male & 8 November 2011 & Skin and skeleton & Oaxaca: Compañía Minera Cuzcatlán, 2.13 km NW San José del Progreso, Municipio San José del Progreso, 1557 m. \\
\hline 47902 & Male & 25 October 2011 & Skin and skeleton & Oaxaca: Compañía Minera Cuzcatlán, 1.88 km NW San José del Progreso, Municipio San José del Progreso, 1559 m. \\
\hline 45122 & Male & 10 January 2008 & Skin and skeleton & Sinaloa: Rancho“La Papalota” 3.1 km N Teacapan, Municipio Escuinapa de Hidalgo, 5 m. \\
\hline 45123 & Male & 28 October 2008 & Skin and skeleton & Veracruz: Panteón Municipal de Tlacotalpan, Municipio Tlacotalpan, 3 m. \\
\hline 45124 & Male & 28 October 2008 & Skin and skeleton & Veracruz: Panteón Municipal de Tlacotalpan, Municipio Tlacotalpan, 3 m. \\
\hline 45125 & Female & 28 October 2008 & Skin and skeleton & Veracruz: Panteón Municipal de Tlacotalpan, Municipio Tlacotalpan, 3 m. \\
\hline 45126 & Female & 28 October 2008 & Skin and skeleton & Veracruz: Panteón Municipal de Tlacotalpan, Municipio Tlacotalpan, 3 m. \\
\hline 45127 & Male & 28 October 2008 & Skin and skeleton & Veracruz: Panteón Municipal de Tlacotalpan, Municipio Tlacotalpan, 3 m. \\
\hline 40769 & Male & 10 April 1999 & Skin and skeleton & Tlaxcala: San Luis 6.1 km NNE Atlangatepec, Municipio Atlangatepec, 2520 m. \\
\hline \multicolumn{5}{|c|}{ Didelphis marsupialis } \\
\hline 7562 & Female & 25 May 1963 & Skin and skeleton & Tabasco: Teapa. \\
\hline \multicolumn{5}{|c|}{ Philander opossum } \\
\hline 3797 & Female & 29 February 1981 & Skin and skeleton & Veracruz: Las Cabañas, Municipio Zontecomapan. \\
\hline \multicolumn{5}{|c|}{ Chironectes minimus } \\
\hline 6960 & Female & 17 December 1962 & Skin and skeleton & Tabasco: Río Puyacatengo, 15 km E Municipio Teapa. \\
\hline \multicolumn{5}{|c|}{ Metachirus nudicaudatus } \\
\hline 34759 & Female & $1990 * *$ & Skin and skeleton & Chiapas: Estación de Biología Chajul, Reserva Montes Azules, Municipio Ocosingo. \\
\hline \multicolumn{5}{|c|}{ Caluromys derbianus } \\
\hline 46855 & Female & 28 August 2012 & Skin and skeleton & Veracruz: Parque Ecológico Jaguaroundi, 1 km WSW La Cangrejera, Municipio Coatzacoalcos, 8 m. \\
\hline \multicolumn{5}{|c|}{ Marmosa mexicana } \\
\hline 29410 & Female & 23 March 1990 & Skin and skeleton & Oaxaca: 11 km SW La Esperanza, camino nuevo a San Isidro Municipio Santiago, 2000 m. \\
\hline \multicolumn{5}{|c|}{ Tlacuatzin canescens } \\
\hline 46539 & Female & 9 April 2013 & Skin and skeleton & Colima: La Encampanada, 6 km E Pueblo Juárez, Municipio Coquimatlán. \\
\hline
\end{tabular}


EPIPUBIC BONES OF D. VIRGINIANA

8 THERYA Vol. 11(1): 1-7 